\title{
Aid for justice? Analyzing the impact of foreign aid on recipient transitional justice implementation
}

\author{
Marc S. Polizzi \\ Murray State University, mpolizzi@murraystate.edu \\ Jeffrey King \\ American University of Sharjah
}

Follow this and additional works at: https://digitalcommons.murraystate.edu/faculty

Part of the Political Science Commons

(c) () (9)

This work is licensed under a Creative Commons Attribution-NonCommercial 4.0 International License

\section{Recommended Citation}

Polizzi, M., \& King, J. (2021). Aid for justice? Analyzing the impact of foreign aid on recipient transitional justice implementation. The International Journal of Human Rights, 1-23.

This Journal Article is brought to you for free and open access by the Faculty Works at Murray State's Digital Commons. It has been accepted for inclusion in Faculty \& Staff Research and Creative Activity by an authorized administrator of Murray State's Digital Commons. For more information, please contact msu.digitalcommons@murraystate.edu. 


\title{
Aid for Justice? \\ Analyzing the Impact of Foreign Aid on Recipient Transitional Justice Implementation
}

\author{
Marc Polizzi \\ Murray State University \\ Jeffrey King \\ American University of Sharjah
}

\begin{abstract}
Some limited scholarship, focused on the US as donor, links the allocation of foreign aid to the implementation of transitional justice (TJ) mechanisms in postauthoritarian recipient states. However, no scholarship systematically examines the link between aid from the global donor population and the implementation of TJ mechanisms more generally. Further, we know little about how foreign aid influences the types of mechanisms that recipients implement because of aid. According to work on the "justice cascade," the international community (ie. donor states) advance criminal accountability of former perpetrators in the transitional process, often at the expense of other transitional goals. In this piece, we first look at the link between the allocation of aid and the likelihood of adoption of TJ mechanisms in post-authoritarian recipient states, arguing that donors emphasize the use of aid for criminal accountability in recipient states. We then explore the role political risk plays in determining the allocation of aid to post-authoritarian recipient states, arguing that in states with higher levels of political risk donors are less likely to give aid. Our expectations are broadly and consistently confirmed.
\end{abstract}




\section{Introduction}

Since the end of World War II (WWII), hundreds if not thousands of transitional justice (TJ) mechanisms have been adopted in a variety of post-civil conflict and post-authoritarian regimes. ${ }^{1}$ With the use of TJ has come questions relating to the financial cost of these mechanisms as well as the effect that they have on the stability of the transitioning state. ${ }^{2}$ The use of trials has been of particular interest within this debate. On the one hand, scholars have argued that trials have a potential destabilizing effect on the transitioning state in comparison to other mechanisms. ${ }^{3}$ Moreover, some scholarship has argued that trials are the most financially costly transitional justice mechanisms, with transitioning states being forced to choose between 'justice' and addressing issues such as the economy instead. ${ }^{4}$ Given the expensive nature of trials, some have argued that states may not ignore transitional justice entirely, but might choose a less expensive alternative, such as truth commissions or amnesties instead. ${ }^{5}$ Given the political realities of the transitional state, these alternatives might also mitigate the potential of a backlash effect by perpetrators. ${ }^{6}$ Such a framing of TJ implementation indicates that there is a financial trade-off in which some post-authoritarian states may be forced to choose between punishing perpetrators and "forgiving and forgetting" based upon the presence/absence of funding for TJ.

Many of the conclusions of this nature, however, are predicated on the domestic funding of TJ, paying less attention to the increasingly prevalent role that the international community has in funding and potentially dictating the implementation of TJ in post-authoritarian states. Given resource constraints of nascent democracies, many international actors have increasingly funded TJ implementation. ${ }^{7}$ One relatively unexplored source of international funding is that of foreign aid. Existing work that does analyze the impact of international aid focus on the U.S. ${ }^{8}$ or funding of specific mechanisms such as UN-led tribunals. ${ }^{9}$ Foreign aid has been a prevalent financial resource for many recipient states since the end of $\mathrm{WWII}^{10}$ and has been used to promote a variety of similar purposes as transitional justice. ${ }^{11}$ Therefore, it is necessary to ask: What effect does foreign aid have on the likelihood of post-authoritarian states implementing TJ mechanisms? 
But with the possible use of aid to promote $\mathrm{TJ}$ in post-authoritarian states is that donors may try to dictate how TJ is implemented (ie. focusing on specific mechanisms). Some evidence also points to substantially less funding going to truth commissions as compared to international tribunals, which may indicate different reputational benefits for funders. ${ }^{12}$ For liberal democracies, in particular, donor states lead by example by providing resources to international war tribunals. ${ }^{13}$ These reputational benefits are a function of strengthening international human rights norms, especially the strengthening of individual criminal accountability in a process known as the 'justice cascade' ${ }^{14}$ However, this outcome could mean post-authoritarian states potentially prioritize punishment to more victim-oriented objectives. Thus, we ask: Do donors pressure states to engage in particular types of transitional justice?

In this paper, we look at the effect that foreign aid has on the implementation of TJ mechanisms in post-authoritarian recipient states. We begin our exploration by first looking at the effect of foreign aid on TJ implementation, arguing that more foreign aid increases the likelihood of implementation in recipient states. We then argue that donors have preferences for specific types of mechanisms, preferring retributive justice mechanisms (i.e., trials) to hold individual perpetrators criminally accountable. However, in our initial examination we find evidence of donors being 'risk averse' when allocating aid to post-authoritarian states. Given this, we then argue that the level of political risk within the state greatly determines the allocation of aid packages for transitional states. For example, when the international community allocates these packages, they act as investors in markets. Investors do not want to provide huge sums of money and end up with a "low return." When applying this logic to international justice 'investors,' donors do not want to provide substantial aid packages to high-risk states that are unlikely to develop into stable democracies. Therefore, these investors allocate aid packages with an eye to the degree of political instability within the state and the likelihood that these states will successfully transition. In testing these assertions, our expectations are broadly and consistently confirmed. 
We organize this paper in the following way. First, we address the literature on transitional justice and foreign aid. Second, we outline our causal explanation for why foreign aid allocations affect transitional justice processes. Next, we outline the operationalization of our models. Finally, we discuss the results of our models, including implications for future research.

\section{Peace vs. Justice: Maintaining Stability}

Transitional justice refers to the collection of 'processes designed to address past human rights violations following periods of political turmoil, state repression, or armed conflict'. ${ }^{15}$ While variation exists based on the post-atrocity setting, common objectives include punishing perpetrators, repairing the damage done to victims, and constructing institutions conducive to long-term peace. Significant debate still exists regarding which mechanisms (or combinations of mechanisms) are likely to achieve a stable transitional environment and the prevention of democratic backsliding. ${ }^{16}$ Moreover, the make-up of the institutional environment can serve as a substantial roadblock to the formulation of post-authoritarian transitional justice. ${ }^{17}$

While not mutually exclusive categories, there are three distinct justice models. First, reparative justice aims to provide restitution to victims to mend the damage done during autocratic rule, typically via monetary reparations. Second, restorative justice provides victims an avenue to express grievances and document abuses, most commonly with truth commissions that give previously marginalized peoples a voice in the process. Finally, retributive justice seeks to punish perpetrators for individual criminal acts, usually through trials. ${ }^{18}$

The transitioning regime's ability to hold perpetrators accountable varies greatly and is largely contingent upon the political dynamics of the transitional system. To better understand this variance, Olsen, Payne, and Reiter outline an accountability spectrum that ranges from "minimalist" to "maximalist" mechanisms. ${ }^{19}$ Minimalist accountability corresponds with amnesties of individual perpetrators, whereas maximalist approaches are trials for perpetrators. States rarely find themselves on either end of the spectrum, instead using some combination of mechanisms that reflects political realities. In fact, Olsen, Payne, and Reiter find this holistic 
approach to be more conducive to achieving stable democratic transitions and positive human rights conditions. ${ }^{20}$ Likewise, international advocates are increasingly supportive of this more balanced form of accountability, one that incorporates some form of prosecutions with amnesties and truth-seeking. ${ }^{21}$ While the nature of the atrocity often demands a certain conceptualization of justice, practical limitations often determine the make-up of TJ (Nobles 2010). One of the largest limitations that transitional states face is the resources available, with states often facing limitations in its ability to construct expensive, and potentially destabilizing trials, and other pressing economic concerns. ${ }^{22}$ Given this, the international community, particularly the West, has taken a more active role in funding TJ. ${ }^{23}$

We argue that the international community is most focused on international security, and as such, an emphasis is largely placed on retributive justice as a means of punishing atrocity perpetrators and deterring future abuse. ${ }^{24}$ Conflicts rarely remain contained within national borders, and as they spread, they threaten regional stability and spark wider humanitarian crises. ${ }^{25}$ Other scholars contest that implementing trials when perpetrators are still entrenched in power incentivizes spoilers to fight back, thereby derailing post-atrocity peace. ${ }^{26}$ But this does not account for the dynamic nature of justice efforts. As Kaufman states, 'Whether transitional justice fosters or hampers international security depends on the particular transitional justice option pursued, its location, its scope, and its pace' ${ }^{27}$ Despite the pull of other economic concerns in the democratization process, growing pressure by international activists means ignoring accountability altogether risks signaling the nascent regime's weak commitment to democratic values. ${ }^{28}$ Indeed, international civil society demands for accountability can sometimes be stronger than domestic pressure. ${ }^{29}$

Despite skepticism, the individual criminal accountability norm is becoming a prerequisite for democratic transitions. While this norm's origins are largely rooted in the Nuremburg and Tokyo Trials following WWII, this accountability model did not take prominence as a global norm until the third wave of democratization and the implementation of trials at the domestic level in transitional regimes like Greece, Portugal, Argentina, Bolivia, and Guatemala. ${ }^{30}$ These 
incoming leaders made efforts to hold former administrations accountable for human rights abuses. While there are multiple sources that have aided in the development of this justice cascade, ultimately the international human rights regime-including human rights NGOs, individual states, and international organizations - has become increasingly devoted to holding perpetrators accountable for human rights atrocities. ${ }^{31}$ But even with the growth in the use of TJ globally, questions remain as to the conditions conducive for the implementation of these procedures or the quality of post-authoritarian justice. In the next section, we outline the existing literature on mechanisms of transitional justice implementation—both internally (e.g., domestic) and externally (e.g., international). As such, donors must assess the trade-offs between shortterm security threats with long-term justice efforts.

\section{Transitional Justice Implementation}

Under what conditions is a state likely to contend with its history of human rights atrocities? Existing literature puts forth several factors to explain the implementation of these structures in the post-authoritarian environment. Borrowing from the work of Elster and Kaminski, Nalepa, and O'Neill, ${ }^{32}$ these factors can be divided into two categories: domestic (i.e., administered by the transitional society itself) or international (i.e., pursued by those outside of the transitional state). ${ }^{33}$ Existing theories test the effects of the distribution of power in the nascent regime between new and old elites, ${ }^{34}$ the duration of authoritarian rule, ${ }^{35}$ the pervasiveness of human rights atrocities, ${ }^{36}$ if abuse occurred in "distant memory" or recent past ${ }^{37}$ pressure from international human rights advocates ${ }^{38}$ and the state's degree of integration into global norms or economic trade. ${ }^{39}$

Early research focusing solely on domestic sources of transitional justice argued that the motivation for justice would be strongest during the transitional phase, with pressure for these efforts waning over time. ${ }^{40}$ Ultimately, the motivation for justice was simply not enough to warrant risking the security of the post-authoritarian transition. Instead, TJ implementation was highly dependent upon the distribution of power in the new democracy. ${ }^{41}$ If perpetrators maintained significant influence, then the disposition for accountability would be less likely. 
While a significant predictor of post-authoritarian transitional justice, Nobles (2010) argues this analysis largely ignored 'international factors and the effects of time, democratic processes, and emotions'. ${ }^{42}$

Furthermore, new regimes can use $\mathrm{TJ}$ as a signal to the international community of commitment to righting the wrongs of the previous government. Appel and Loyle, ${ }^{43}$ for instance, find that states will implement TJ domestically to attract foreign direct investment (FDI). Investors are likely uneasy about investing in a fragmented society that might have weak rule of law. As such, transitioning regimes will implement TJ as a costly signal to nervous investors of the state's commitment to rule of law. While the authors empirically test this hypothesis using restorative measures of justice (i.e., truth commissions and reparation programs), it stands to reason that, with the expansion of the individual criminal accountability norm by the international community, investor confidence would also heighten with the implementation of tribunals and other retributive mechanisms as well.

\section{The Role of Foreign Aid}

Another important, yet largely unexplored, external source of funding that explains is the use of foreign aid by donor states. The first mass use of foreign aid came under the Marshall Plan and was used to promote the economic recovery of post-war Western Europe. ${ }^{44}$ Since then, according to Tierney et al., ${ }^{45}$ the official purpose of the vast majority of foreign aid allocated to recipient states has been for promotion of economic development in recipient states. As stated by Tierney et al. 'since 1945 , wealthier countries have allocated more than $\$ 4.9$ trillion to developing nations for the nominal purpose of lifting the world's poor out of poverty ${ }^{46}$. However, one of the more common topics in the foreign aid literature focuses on the elusive link between what is termed official development assistance (ODA) and economic growth in recipient states, with many scholars concluding that the official purpose of foreign aid may be for

development but donors largely use aid for other purposes. ${ }^{47}$ Therefore, aid has largely been an instrumental tool of donor states in the pursuit of various strategic objectives, such as the 
containment of communism during the Cold War. ${ }^{48}$ Thus, historically, donors have mostly used ODA in the pursuit of non-ODA strategic objectives.

A number of recent studies have also demonstrated that aid can be used by donors to promote positive changes in recipient states, such as by supporting the democratization process. Knack provided the earliest study linking aid to democratization efforts in recipient states and found that global aid efforts did not enhance democracy internationally. ${ }^{49}$ However, Knack tested a global sample of aid allocated to recipient states to democracy levels globally, ignoring that much of the aid in his sample was used for purposes other than democratization. Conversely, other scholars find that U.S. aid allocated specifically for democracy promotion has a positive and significant effect on democratization. ${ }^{50}$ Democracy aid, as this type of targeted aid is now termed,${ }^{51}$ works in several ways. According to Savun and Tirone ${ }^{52}$ states are at their most vulnerable to civil conflict during the democratization process. Democracy aid helps to overcome this time inconsistency problem by strengthening institutions and promoting a civil society conducive to democracy. Similarly, aid increases the transition to multiparty politics while reducing electoral misconduct. Thus, this literature demonstrates that aid can be used to promote democratization within recipient states. These findings are important for our exploration of the factors explaining $\mathrm{TJ}$ implementation because one of the primary purposes of $\mathrm{TJ}$ is to strengthen democratic processes in post-transition states. ${ }^{53}$

Meanwhile, the literature linking foreign aid and human rights conditions in recipient states is limited at best. Much of this literature has focused on the effect of aid lending from powerful international organizations such as the IMF and World Bank, with the focus being on the structural-adjustment conditions placed on recipient states rather than on aid directly. ${ }^{54}$ Further, early studies looking at aid and human rights conditions suggest that donors rewarded states with poor human rights records during the Cold War period, calling into question the use of aid to improve conditions in recipient states. ${ }^{55}$ Other scholars argue that aid, by itself, is an ineffective means of influencing government policy towards human rights conditions in recipient states. ${ }^{56}$ Since then, the literature linking human rights and foreign aid has been sporadic at best. 
Nielsen, ${ }^{57}$ for example, looks at whether donors punish repressive recipient governments by reducing aid flows and finds that donors are hesitant to reduce aid to politically proximate governments. Literature of the type above highlight that foreign aid may not play a significant role in the improvement of human rights in recipient states. However, Richards et al.$^{58}$ find that foreign economic penetration, of which foreign aid is a type, can and does influence the adoption of policies within recipient states. Thus, this suggests that foreign aid could play a role by inducing recipient states to adopt $\mathrm{TJ}$ mechanisms.

Given that donors have used foreign aid to promote objectives like democratization, the improvement of human rights, or even just the pursuit of strategic objectives, it should come as no surprise that donors might use foreign aid to promote TJ mechanism implementation. With that being said, the literature linking foreign aid to transitional justice is quite limited, and focuses on why donors choose to allocate foreign aid in support TJ. According to Arthur, ${ }^{59}$ for example, donors — especially bilateral donors — use aid instrumentally in pursuit of further goals beyond TJ. Donors allocate aid, for example, in pursuit of further democratization, development, or as a means of promoting stability within a state, but $\mathrm{TJ}$ is not the end goal when aid is being allocated to promote it. Further, strategic objectives remain paramount in donor calculations, and donors do not allocate aid for TJ that contradicts strategic interests. Arthur argues in her conclusion that we should expect donors to pursue TJ using aid, ${ }^{60}$ but only when it furthers their strategic interests. Conversely, Arthur argues that donors cannot be expected to use aid in pursuit of TJ when aid might increase the risk of instability within the recipient state, which would threaten the donor's strategic objective. Thus, the use of aid for TJ is not that dissimilar to donors' calculations when allocating aid more generically, but donors seem to consider risk as a further factor when pursuing TJ implementation.

\section{States as Investors}

As the transitional justice literature outlined above demonstrates, the culture of impunity at the international level has largely been replaced by individual criminal accountability. However, most TJ states are middle- and lower-income, meaning domestic funding for these mechanisms is 
nearly impossible with competing needs for rebuilding the state (Arthur 2018). ${ }^{61}$ As such, TJ states often turn to the international community for financial assistance of these procedures, and we predict that these states will pursue justice that is consistent with international norms. ${ }^{62}$ Specifically, we expect states to implement trials as the main avenue of accountability.

Even if the new regime indicates its willingness to pursue prosecutions, this does not necessarily mean these new actors desire a complete end to the culture of impunity. These new actors are largely untested democratic actors. As there are an abundance of cases of democratic backsliding, new regimes can succumb to the same sins as their predecessors and use repressive tactics to coerce dissenters or as an instrument to punish former regime actors. The recent case of human rights abuses against the Rohingya in Myanmar serves as an unsettling example. As such, donors face an adverse selection problem, similar to the effect observed in humanitarian interventions. ${ }^{63}$

Expanding upon work that explored humanitarian interventions as a moral hazard, ${ }^{64}$ Rauchhaus describes an adverse selection issue resulting from asymmetric information between a potential intervener and the parties in the conflict. ${ }^{65}$ The intervening state does not know the true preferences of these actors and therefore must use information short cuts to make sure domestic actors uphold the contract. Turning to TJ, because nascent democratic regimes are untested, potential donors do not know that the state will uphold its commitment to accountability, rule of law, or democratic institutions — which are objectives that the international community prioritizes. ${ }^{66}$ Therefore, donors must turn to alternative means of information-a shortcut to having perfect information about the recipient. The recipient's level of political risk serves as this shortcut.

Recent work by Arthur indicates a high degree of variability by foreign governments for transitional justice. ${ }^{67}$ This problem is amplified when looking at multilateral TJ projects that include networks of states, international organizations, and non-governmental advocates. Even within states that prioritize TJ as a focus of their foreign policy, these countries often lack any formal institutionalization of these procedures. Instead, 'TJ continues to fit into existing 
institutional structures in a highly variable way, and it generally lacks policies or even dedicated focal points to guide decision-making and coordination' ${ }^{68}$. Additionally, states spend social capital in addition to monetary and technical costs and would want to spend resources in locations that will produce the greatest expansion of their soft power. ${ }^{69} \mathrm{Japan}$, for instance, was a primary contributor to transitional justice in Cambodia, while not providing similar funds anywhere else in the world. Japan's assistance to justice in Cambodia was 'partly motivated by its wish to project its power regionally ${ }^{70}$. Other research on international tribunals also points to a regional bias. ${ }^{71}$ Therefore, we argue that the expected return on these investments matters to donor states and that donors will not invest in overly risky recipient environments as a result.

To summarize, we theorize the relationship between transitional justice and foreign aid based on two interrelated incentive structures. First, new leaders in recipient states desire foreign aid in order to help rebuild the state and its institutions. Democratizing states signal their commitment to accountability by pursuing trials to attract foreign aid from international donors, similar to the findings of Appel and Loyle on TJ and foreign direct investment, whereby they argue that leaders of post-conflict states use $\mathrm{TJ}$ mechanisms as a signal to multinational corporations that the domestic environment is stable and conducive for business. ${ }^{72}$ Second, the domestic incentive for post-authoritarian states to pursue accountability is consistent with the goals of the international community, specifically the normative objective of the justice cascade and individual criminal accountability. Donors work to minimize case-specific information needed to fund the rebuilding of post-authoritarian states. Therefore, donors will look to the recipient's level of political risk in order to determine the best environments in which to invest. Because of these mutually beneficial incentive structures, we predict that the attraction of this aid by postauthoritarian governments ensures the enactment of transitional justice-specifically individual criminal accountability mechanisms in the form of human rights trials.

\section{Hypotheses}

We have divided our hypotheses into two sections. The first is focused on the effect of the provision of foreign aid on the implementation of TJ mechanisms. Here we look at whether the 
allocation of foreign aid increases the likelihood of recipients implementing TJ mechanisms and argue that when recipient states receive more foreign aid, they are more likely to implement transitional justice mechanisms. In this instance, aid acts as an added resource for the recipient to use to recover from the transition from authoritarianism. ${ }^{73}$ Recipients use aid to fund TJ efforts in this manner. Thus, as foreign aid increases, this should also increase the number of TJ implemented. Therefore, our first hypothesis is simply:

H1: Post-authoritarian states that receive a higher degree of foreign aid are more likely to implement transitional justice mechanisms than states that receive less aid.

Moreover, the international community influences the type of transitional justice mechanisms that these states employ. Using the literature emphasizing the expansion of international norms, ${ }^{74}$ we argue that the international community has traditionally encouraged individual criminal accountability for perpetrators over a culture of impunity, specifically through trials. Thus, states receiving more aid should be under increased pressure to implement transitional justice mechanisms in the form of human rights trials ${ }^{75}$. From this argument we provide our second hypothesis:

\section{H2: Post-authoritarian states that receive a higher degree of foreign aid are more likely to} implement human rights trials than states that receive less aid.

The second part of our analysis focuses on whether the political stability of the recipient state influences the amounts of aid received and the likelihood of TJ mechanisms being implemented. We argue that less-stable states (ie. high risk) are seen as riskier investments by donors and as a result, these states should be less likely to receive aid for the purpose of TJ mechanism implementation. This is due to donors viewing aid for TJ as an investment. They give more aid when transitional justice mechanisms further certain strategic objectives, but less aid when these mechanisms might risk those same strategic objectives. In effect, in less stable states these mechanisms are seen as a risk to the strategic objectives of donors - regardless of whether these objectives are democratization, state stability, or so forth — and aid is seen as a "bad investment". 
Due to this, these states should be less likely to receive both aid for the purpose of TJ mechanism implementation and less aid at the aggregate level also. Thus, our third hypothesis is:

\section{H3: Post-authoritarian states that are considered politically unstable are less likely to receive foreign aid than states that are considered more politically stable.}

\section{Research Design}

In this paper, we are primarily concerned with the transitional justice mechanisms that are implemented in post-authoritarian recipient states. Given that, our sample is comprised of the global population of post-authoritarian states that were allocated foreign aid. Within our sample are different types of authoritarian regimes such as dictatorships, military juntas, or one-party rule that went through a transition to democracy. Our unit of analysis is the post-authoritarian recipient-year for the period of 1990 to 2002 for 129 recipient states.

To create our sample, we utilize the standard of the Authoritarian Regime and Transition Type Dataset (ARTT) developed by Andrew Reiter in conjunction with the Transitional Justice Data Base Project. ${ }^{76}$ The goal of ARTT is to 'test whether the type of authoritarian regime, the length of that regime, or the type of transition to democracy affect specific components of the democratization process or decisions of new democratic leaders ${ }^{97}$. This purpose is directly related to what we are addressing within this paper. We are concerned with the actions of newly democratizing states and the incentives that their leaders have in pursuing transitional justice. These incentives are heavily influenced by the nature of the regime, the bargaining position of previous abusers, and the nature of the transition itself. As Huntington argues, new democratic leaders will have a more difficult time prosecuting former perpetrators if these same democratic leaders are still affiliated with the government. ${ }^{78}$

For our dependent variables, we utilize different specifications of TJ implementation. Our measures of TJ mechanisms come from the Transitional Justice Database Project from Payne, Olsen, and Reiter. ${ }^{79}$ This dataset compiles information on five major TJ mechanisms: truth commissions, human rights trials, lustration policy, reparations, and amnesties. From this source, we created three separate dependent variables to test our three hypotheses, trying to determine if 
foreign aid has an effect on the implementation of transitional justice in post-authoritarian states. To test our first hypothesis, we simply want to see if states are more likely to engage in any measure of transitional justice. Therefore, we include a count of all five types of transitional justice at the country-year level as our first dependent variable. Second, to test Hypothesis 2, we are concerned with the number of human rights trials that are implemented at the country-year level as a result of foreign aid. As such, we employ a count of trials implemented in a given country-year as our second dependent variable. This approach determines how many individual criminal accountability mechanisms are implemented within the state. ${ }^{80}$ Finally, to test hypothesis three, we created a binary variable measured as 1 if a TJ mechanism was implemented in a given year or 0 if not. Utilizing this binary measure allows us to interact our transitional justice mechanism variables with measure of risk for hypothesis 3 and provides us with some substantive effects.

For our independent variable, we focus on the total amount of foreign aid allocated to individual post-authoritarian recipient states. We use the dataset AidData 2.1 for our foreign aid data. AidData $2.1^{81}$ is the most comprehensive aid dataset available today, with the sample including 289,566 entries for all donor-recipient dyads for the period of 1947 to $2012 .{ }^{82}$ In AidData 2.1, two country-year variables are available, that of commitments and disbursements. We use commitments of aid instead of disbursements of aid in this study because the coverage of the commitments variable is significantly greater than disbursements, with disbursements only covering the post-2002 period $^{83}$, limiting its overlap with the ARTT database. We also must acknowledge that a dataset including aid used specifically to support transitional justice would be most appropriate here, but unfortunately do not have access to data of that type to date. We use a human rights aid ${ }^{84}$ variable in our robustness checks to address this lack of TJ aid, but this data also does not fit well with the ARTT database. Thus, we ultimately use the natural logarithm of the total amount of commitments of aid recipients receive by year in US millions of dollars as our foreign aid variable. 
We control for a variety of factors based on the conditions of the previous authoritarian regime, the nature of the transition, the length that the government was under authoritarian leadership, as well as numerous characteristics of the state's political and economic performance. These factors help avoid spuriousness in our relationship. Previous research indicates a variety of factors regarding the elements of the previous regime - and how well ingrained they are in the newly democratized state-will determine the ability of new leaders to pursue transitional justice, or even the type of justice implemented (Huntington 1991; Nobles 2010; Olsen, Payne, and Reiter 2010a). When there is not a clear break between the previous regime and the new regime, it becomes more difficult for former leaders to prosecute perpetrators for fear of destabilizing the transitional process. ${ }^{85}$ Prosecutorial sovereignty is greater in cases when there is a clear break from the previous regime and in cases where the balance of power is favorable to the new regime. ${ }^{86}$ Other efforts are largely compromises between domestic and international pressure for accountability on the one hand and the protection of perpetrators against prosecution on the other hand. Such efforts relate to reconciliation and is the main reason for the creation of truth commissions.

For the conditions of authoritarianism, we utilize the ARTT dataset. First, these data determine the type of autocracy based on characteristics, such as individualism or institutionalism and civilian or military regime. Regime length simply determines 'the length of time, in years, that the authoritarian regime that immediately precedes the transition to democracy held power ${ }^{87}$. Transition type includes factors such as if the regime was overthrown (either from domestic or international forces), if the regime collapsed completely, and if the regime came from a negotiated settlement (led either by the regime or the opposition). This variable also determines if democracy emerged from civil war or if the democratic regime emerged upon independence.

Finally, we include a number of control variables relevant to both aid efforts and transitional justice efforts in recipient states. We include the regime-type of the recipient state, with the assumption that more democratic states have better human rights conditions. ${ }^{88}$ Further, many 
donors have historically allocated more aid to former colonial territories, making it necessary to control for colonial histories ${ }^{89}$ Related to this, the legal traditions of metropoles often manifest in similar legal traditions in the former colonies.$^{90}$ In turn, the legal traditions within the recipient state potentially act as predictors of whether transitional justice mechanisms are adopted and in what form they take, making it necessary to control for legal traditions. ${ }^{91}$ These measures are also utilized to address potential omitted variable bias. Given that our sample is recipient aid totals by year, we cannot directly factor in the strategic interests donor states might have in recipient states. Instead, we can only address this indirectly by including such measures of former colonial ties and other related proxies. ${ }^{92}$ Finally, both the wealth of the state and population of the state have been linked to human rights conditions. ${ }^{93}$

To carry out the analysis, we included a number of models and approaches to estimate the effect of foreign aid on the implementation of $\mathrm{TJ}$ mechanisms in post-authoritarian recipient states. In the first part of our analysis, results included in Table 1, we provide two models using our two TJ count variables (Full Count, Trials respectively) as dependent variables to test Hypotheses 1-2 in Models 1-2. We utilize negative binomial regression models with each rightside variable lagged by one year. In the second part of the analysis, in Table 2, we are interested in the effect of political risk on aid totals and TJ mechanisms. We provide a measure of political risk taken from the International Country Risk Guide (ICRG) on the right side of Models 1 and 2 that is interacted with our aid variable in each model. To provide substantive effects of the interactive effect of foreign aid and political risk on implementation, we utilize the binary measure of TJ implementation in Model 1 of Table 2 along with the total count of TJ implementation in Model 2. Each model included in the analysis is also fitted with robust standard errors to control for heteroscedasticity. ${ }^{94}$

\section{Findings}

For the first part of our analysis, we analyze how international aid commitments influenced the number of $\mathrm{TJ}$ mechanisms implemented within a state. Table 1 demonstrates these findings below. As is shown in Model 1, states that received higher levels of aid commitments 
implemented more transitional justice mechanisms, providing support for Hypothesis 1. Further, we looked at whether commitments also influence the type of transitional justice. Model 2 shows that aid commitments are associated with the number of human rights trials implemented within the state. Therefore, we can argue that states that receive more international commitments are more likely to pursue accountability mechanisms, providing support for Hypothesis 2. Looking at our results, a number of control variables are significant as well. The human rights score of recipient states in both models is negative and highly significant, suggesting that recipients with better human rights are less likely to implement transitional justice mechanisms. In contrast to that, legal origins, whether English or socialist/communist, seems to increase the likelihood of transitional justice implementation. Meanwhile, regime type does not have a significant effect on overall count or trials. In contrast, states are less likely to implement trials after transitioning from a civil war. This finding, in particular, may provide some support for our theory of risk in Hypothesis 3, because trials in this instance might be quite 'risky' and destabilize the state.

Table 1: Negative Binomial Regression, The Effect of Total Aid Commitments on Transitional Justice Implementation in Post-Authoritarian States

\begin{tabular}{lcc}
\hline & $(1)$ & $(2)$ \\
VARIABLES & $\mathrm{TJ}_{(t+1)}$ & $\mathrm{Trials}_{(t+1)}$ \\
\hline Commitments $(\ln )$ & $0.11508^{* *}$ & $0.20226^{* *}$ \\
& $(0.054)$ & $(0.101)$ \\
Fariss Human Rights & $-0.46145^{* * *}$ & $-0.61013^{* *}$ \\
& $(0.129)$ & $(0.256)$ \\
Polity 2 & -0.01931 & -0.01663 \\
& $(0.015)$ & $(0.034)$ \\
Population $(\ln )$ & -0.10045 & $-0.34629 *$ \\
& $(0.090)$ & $(0.191)$
\end{tabular}




\begin{tabular}{|c|c|c|}
\hline GDP per capita (constant) (ln) & $\begin{array}{c}-0.15236^{*} \\
(0.090)\end{array}$ & $\begin{array}{c}-0.05991 \\
(0.185)\end{array}$ \\
\hline International Conflict & $\begin{array}{l}0.31787 \\
(0.350)\end{array}$ & $\begin{array}{c}-0.18628 \\
(0.754)\end{array}$ \\
\hline Civil Conflict & $\begin{array}{c}-0.13060 \\
(0.324)\end{array}$ & $\begin{array}{c}-0.34796 \\
(0.761)\end{array}$ \\
\hline HRO Count & $\begin{array}{c}0.05234 \\
(0.150)\end{array}$ & $\begin{array}{c}0.43549 \\
(0.290)\end{array}$ \\
\hline English Legal Origin & $\begin{array}{c}1.30546^{* *} \\
(0.538)\end{array}$ & $\begin{array}{c}33.90108 * * * \\
\quad(1.560)\end{array}$ \\
\hline SocComm Legal Origin & $\begin{array}{c}1.37031^{* * * *} \\
(0.459)\end{array}$ & $\begin{array}{c}18.10257^{* * *} \\
(2.059)\end{array}$ \\
\hline Age of Democracy & $\begin{array}{c}-0.00427^{*} \\
(0.003)\end{array}$ & $\begin{array}{l}0.00297 \\
(0.005)\end{array}$ \\
\hline Civil War Transition & $\begin{array}{c}-0.25228 \\
(0.682)\end{array}$ & $\begin{array}{c}-16.76927 * * * \\
(0.833)\end{array}$ \\
\hline Collapse & $\begin{array}{l}-0.02930 \\
(1.287)\end{array}$ & $\begin{array}{c}-0.43135 \\
(1.194)\end{array}$ \\
\hline Overthrow & $\begin{array}{l}0.89015 \\
(0.889)\end{array}$ & $\begin{array}{l}1.71136 \\
(1.101)\end{array}$ \\
\hline Sudden Transition & $\begin{array}{l}0.46783 \\
(0.819)\end{array}$ & $\begin{array}{c}2.13052^{* *} \\
(0.959)\end{array}$ \\
\hline Constant & $\begin{array}{c}-0.88969 \\
(1.546)\end{array}$ & $\begin{array}{c}-20.25130 * * * \\
(3.246)\end{array}$ \\
\hline Observations & 1,595 & 1,595 \\
\hline
\end{tabular}

In the first part of our analysis, we looked at whether foreign aid increases the likelihood of the implementation of $\mathrm{TJ}$ mechanisms. In the second part of our analysis, we instead look at 
whether donors give aid in general to states that implement TJ mechanisms, building up to testing hypothesis 3. Looking at Figure 1 below, for example, we can clearly see that states that implemented TJ mechanisms of any kind actually received substantially less aid in comparison to those that did not implement TJ mechanisms. In Figure 1, the global aid totals (in \$U.S. millions) are split into two categories. The first category is the sum total of all aid received by nontransitional justice recipients. The second category is the sum total of all transitional justice recipients. Looking at the figure, recipients without any TJ mechanisms in a given year received an average of approximately $\$ 86$ billion per year of commitments of aid. In contrast, the TJ recipients received only $\$ 22.5$ billion per year in commitments of aid. This result may seem surprising, suggesting that donors are not giving aid to recipients for TJ purposes. However, this is a separate test from our first analysis, as now we are looking at factors that explain why donors might give aid (or in this case not give) aid to recipient states. What these findings show is that donors do not seem to give aid to states that have implemented TJ mechanisms, suggesting that there is some other unexplored but relevant factor at play that explains aid flows to recipient states.

Figure 1: A Comparison of Aid Commitments for Transitional Justice Recipients versus NonTransitional Justice Recipients 


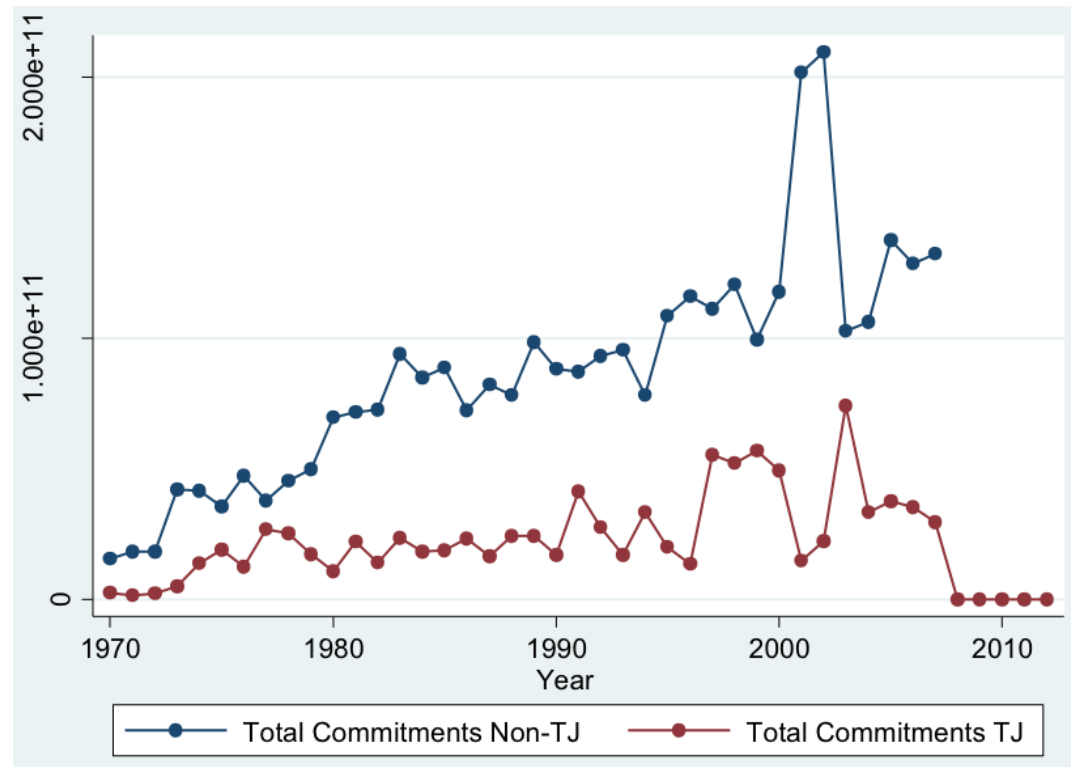

Transitional justice recipients also vary by the number of TJ mechanisms implemented in recipient states as well. Looking at Figure 2, we can see that more TJ mechanisms implemented by recipients decreases aid efforts to those states. In the figure, we disaggregate aid totals to the total count of TJ mechanisms implemented per year by the recipient. Looking at the figure, we can see that states that implemented one TJ mechanism received the most commitments of aid over time. In contrast, states that implemented three or four TJ mechanisms received the least amounts of commitments of aid. Thus, there appears to be some hidden factor present that is explaining disparities in aid totals between TJ recipients and non-TJ recipients and with the number of TJ mechanisms implemented.

Figure 2: A Comparison of Aid Commitments for Transitional Justice Recipients Disaggregated by the Number of Transitional Justice Mechanisms Implemented 


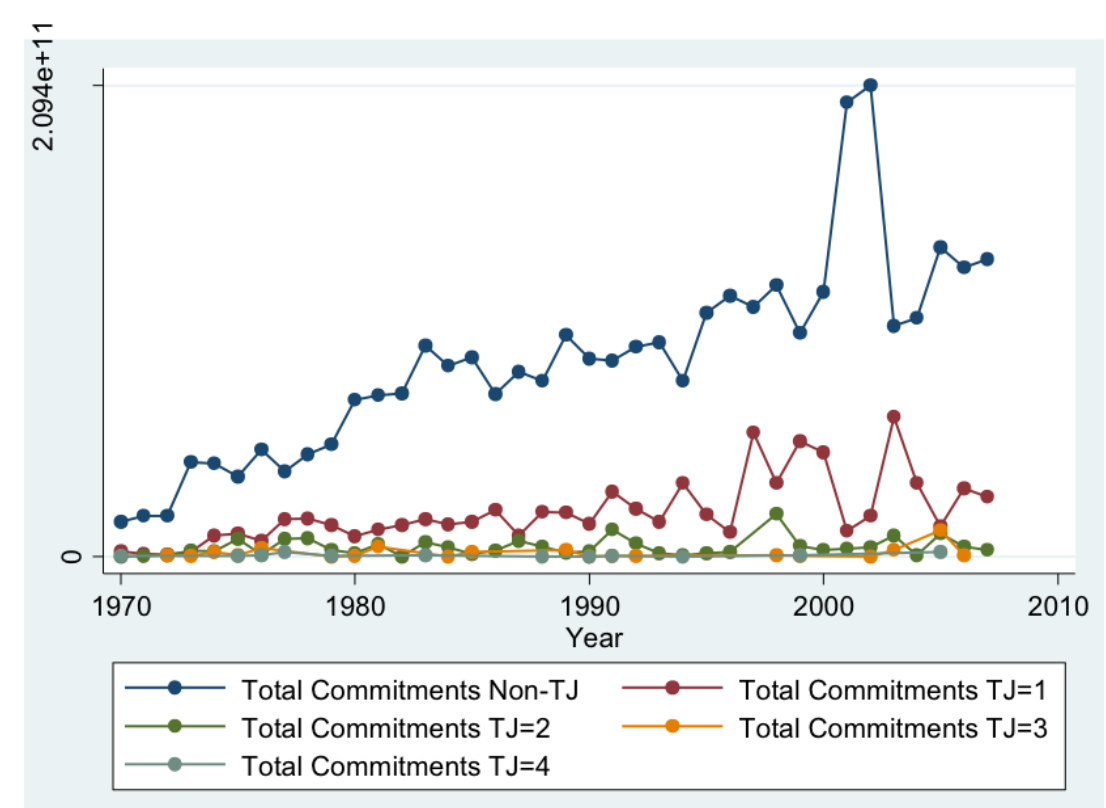

What explains the disparities highlighted in Figures 1 and 2? One reason why these disparities exist, we theorize, is due to the risk calculations of donor states. This sample is of post-authoritarian states. For donor states, allocating aid to these states is considered a risk from the beginning, because any aid given could easily be misappropriated and misused by the recipient government. Thus, when donors consider a potential recipient state to be unstable and "risky" for the donor, they are hesitant to give aid period. Coupled with this, transitional justice mechanisms are often considered particularly risky for these sometimes highly unstable states. Research by Huntington and Vinjamuri and Snyder displayed fear of a rise in post-authoritarian violence as perpetrators would lash out in violence when faced with prosecution. ${ }^{95}$ This violence could destabilize the transitional process, risking a return to civil conflict or backslide into authoritarianism. As a result, recipients deemed high risk are unlikely to receive large amounts of aid from donors.

To test this assertion, a risk variable was added to the base model specifications in Table 1 using both a binary dependent variable (Model 3) and a count dependent variable (Model 4) that was then interacted with commitments of aid to test if there was any interactive effect between aid and risk. Looking at the results, we can see that this appears to be the case. Looking at Model 3 
and Model 4 in Table 2, both constitutive terms of the interactive effect are significant at 0.05 . Commitments has a negative and significant effect in the absence of risk, suggesting that the more aid committed to the recipient state, the less likely a TJ mechanism will be implemented. Further, when the risk score of the recipient state increases, signifying less risk because high scores signify more stable states, this also decreased the probability of a TJ mechanism being implemented. However, when those two terms are interacted with each other, we can see that when commitments increase and risk decreases, the probability of a TJ mechanism also increases. In fact, when the risk score of the state moves from the highest risk (20) to lowest (91), foreign aid shifts from negative and insignificant to positive and significant at .05, strongly supporting hypothesis 3 . Ultimately, this suggests perceptions of risk, must be accounted for before we can expect that aid will increase the likelihood of TJ mechanisms being implemented.

Table 2: The Effect of Total Aid Commitments and Political Risk on Transitional Justice Implementation in Post-Authoritarian States

\begin{tabular}{lcc} 
VARIABLES & $\mathrm{TJ}_{(t+1)}$ & Count of TJ $(t+1)$ \\
\hline Commitments $(\ln )$ & $-0.85081^{* *}$ & $-0.78663 * *$ \\
& $(0.383)$ & $(0.267)$ \\
Political Risk & $-0.29515^{* * *}$ & $-0.27852^{* * *}$ \\
& $(0.111)$ & $(0.077)$ \\
Commitments*Risk & $0.01409 * *$ & $0.01312 * * *$ \\
& $(0.006)$ & $(0.004)$ \\
Fariss Human Rights & -0.28926 & -0.15903 \\
& $(0.262)$ & $(0.244)$ \\
Polity 2 & 0.00319 & -0.00252 \\
& $(0.031)$ & $(0.030)$ \\
Population (ln) & 0.04580 & 0.05209 \\
& $(0.149)$ & $(0.132)$ \\
GDP per capita (ln) & -0.14341 & -0.17694 \\
& $(0.144)$ & $(0.131)$
\end{tabular}




\begin{tabular}{|c|c|c|}
\hline Interstate Conflict & $\begin{array}{l}1.7443^{*} \\
(0.629)\end{array}$ & $\begin{array}{c}0.73582 * * \\
(0.351)\end{array}$ \\
\hline Intrastate Conflict & $\begin{array}{c}-1.04008 \\
(0.640)\end{array}$ & $\begin{array}{c}-0.57817 \\
(0.352)\end{array}$ \\
\hline HRO Count (ln) & $\begin{array}{l}0.23144 \\
(0.406)\end{array}$ & $\begin{array}{c}0.30113 \\
(0.335)\end{array}$ \\
\hline English Legal Origin & $\begin{array}{l}0.51251 \\
(1.020)\end{array}$ & $\begin{array}{c}0.35843 \\
(0.925)\end{array}$ \\
\hline French Legal Origin & $\begin{array}{c}-0.01925 \\
(1.072)\end{array}$ & $\begin{array}{c}-0.05121 \\
(0.961)\end{array}$ \\
\hline SocComm Legal Origin & $\begin{array}{l}0.86151 \\
(1.156)\end{array}$ & $\begin{array}{c}0.78119 \\
(1.036)\end{array}$ \\
\hline German Legal Origin & & $\begin{array}{c}-17.82590 * * * \\
(1.137)\end{array}$ \\
\hline Scand Legal Origin & & $\begin{array}{c}-18.93362 * * * \\
(1.495)\end{array}$ \\
\hline Age of Democracy & $\begin{array}{c}-0.00568 \\
(0.005)\end{array}$ & $\begin{array}{c}-0.00363 \\
(0.004)\end{array}$ \\
\hline Civil War & & $\begin{array}{c}-20.68480 * * * \\
(0.674)\end{array}$ \\
\hline Collapse & $\begin{array}{l}1.16958 \\
(1.772)\end{array}$ & $\begin{array}{c}0.56892 \\
(1.046)\end{array}$ \\
\hline Overthrow & $\begin{array}{l}1.60256 \\
(1.466)\end{array}$ & $\begin{array}{c}0.97079 \\
(0.782)\end{array}$ \\
\hline Constant & $\begin{array}{c}15.36790 * * \\
(7.453)\end{array}$ & $\begin{array}{c}14.00753 * * * \\
(5.227)\end{array}$ \\
\hline Observations & 848 & 860 \\
\hline
\end{tabular}

We can see this pattern play out using Figures 3 below. Looking at the figure, we can see that commitments of aid crosses the X-axis, suggesting both a positive and negative effect on TJ implementation when interacted with risk, albeit at varying degrees of significance. When the political environment of the recipient is considered to be high risk (lower scores denote more risk), commitments of aid have a negative but insignificant relationship with TJ implementation. 
However, when the political environment of the recipient is considered low risk, commitments of aid increase the probability of transitional justice being implemented at a highly significant level. In fact, we can see the probability shift from -.1 (insignificant) for the riskiest states to .033 (significant at .1) for the most stable states. Thus, it appears as if donors weigh risk as an important part of the story in explaining how aid efforts affect TJ efforts in recipient states.

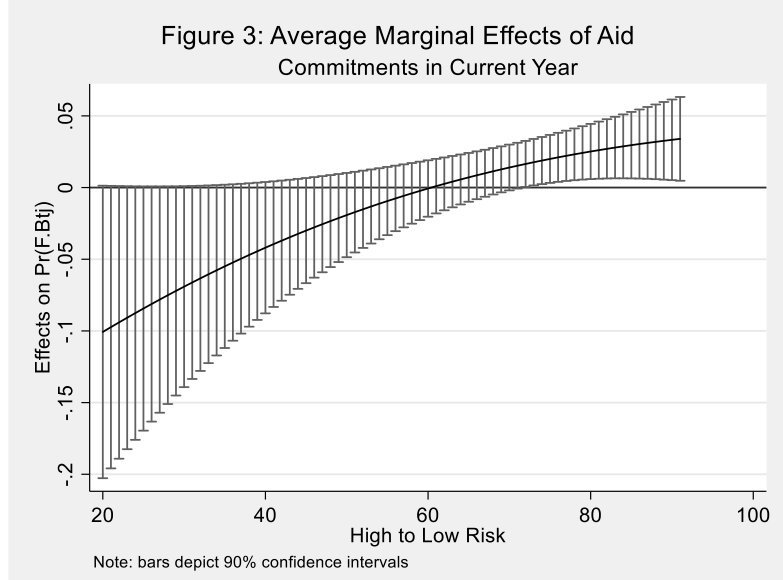

A similar pattern emerged when using the count of transitional justice mechanisms also. Looking at Model 4 in Table 2, we can see that commitments of aid and political risk again have a negative effect on the count of total TJ mechanisms implemented by the recipient state. In contrast, however, the interactive effect is again significant and positive. In this case, as commitments increase and risk decreases, the probability of the count of TJ mechanisms also increases. Similar to Figure 3, we see a substantial shift in Figure 4. The effect of aid, when interacted with risk, goes from negative and insignificant for the highest risk states to a positive and significant effect for the least risky states, representing a shift in probability from -.122 (insignificant) to .022 (significant at .05). Thus, again, it seems that risk is a factor in explaining the amounts of aid as well as whether or not aid is effective in encouraging the implementation of $\mathrm{TJ}$ mechanisms in recipient states. 


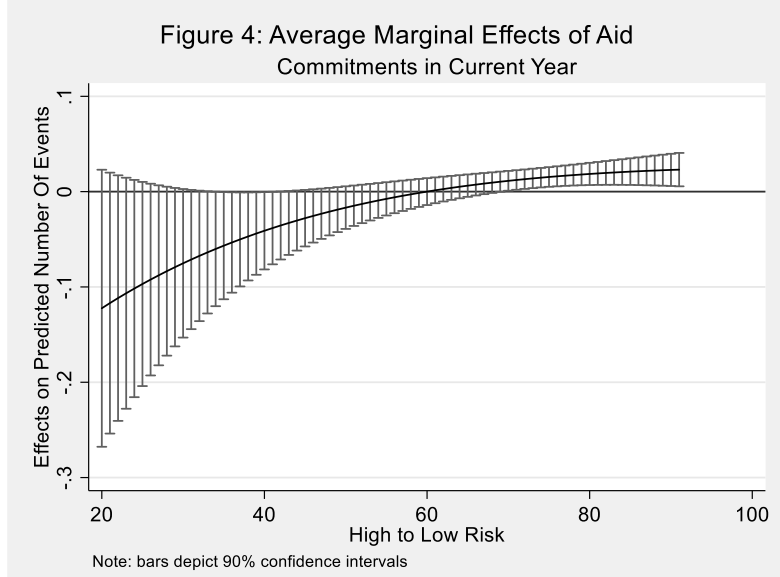

\section{Conclusion}

This paper argues that the international community's use of foreign aid has important implications for the implementation of transitional justice in post-authoritarian states. Building on the work of Kim, ${ }^{96}$ Bird, ${ }^{97}$ and Olsen, Payne, and Reiter, ${ }^{98}$ we argue that the foreign aid donors plays an important role in TJ implementation. We first argue that states that receive greater amounts of foreign aid are more likely to implement transitional justice, specifically accountability mechanisms. Our findings confirmed our expectations and suggest that donor states prioritize justice when supporting the implementation of TJ efforts in recipient states. Further, our initial analysis suggested that the international community acts as investors, determining where to allocate funds based on an analysis of risk in the recipient state. Given this, we employ a measure of risk to test if donors are making calculations based upon perceived risks in TJ states, with our expectations largely confirmed as a result.

The findings contained in this paper have several implications for the broader literature. Perhaps most concerning is that our findings suggest that donors avoid the worst violators of human rights when allocating aid to promote $\mathrm{TJ}$ implementation in post-authoritarian states. If, as we find, donors allocate aid to low-risk post-authoritarian states, then our findings suggest that they are investing in only the most stable (ie. less risky) recipients. These states, although they may benefit from outside support for implementation of TJ, are of a type that would need the least support from donors because violations of human rights are likely to be fewer in quantity 
and less severe in nature. In contrast, in less stable states violations of human rights are more likely to be frequent and severe in nature. These states are most likely still grappling with the legacy of the pre-transition period. In effect, this means that donors may be selecting the "easy" cases to encourage the use of transitional justice mechanisms. But this is a troubling conclusion, because it suggests that milder human rights violators may be held to more stringent standards than major violators in riskier states.

On the other hand, there is evidence to suggest that donors are not the ones doing the selection in the case of transitional justice. Instead, it is plausible that recipients are actually selecting donors by implementing transitional justice mechanisms. Appel and Loyle argue that states use transitional justice mechanisms to signal to international investors and multinational corporations that the state is now 'open for business'. ${ }^{99}$ Recipient states may do something similar to signal to donors that they are suitable for foreign aid allocations. If this is the case, then the relationship is actually reversed, suggesting that there may be a problem with endogeneity in our study ${ }^{100}$. We have provided robustness checks to allay some concerns over this, but further testing is needed to test how recipients attract donor states.

Finally, it is important to consider the relationship between aid and $\mathrm{TJ}$ implementation in post-conflict states also. Transitional justice was developed to address conditions in both postauthoritarian and post-conflict states, aiming to address a broad array of human rights violations. Given this, we would expect our findings to hold for post-conflict states, but there are important differences to consider also. Civil wars tend to last a long time, especially when they are fought using irregular means of warfare. ${ }^{101}$ Furthermore, when there are multiple factions in the conflict, this can make negotiated settlements more difficult to initiate and to ensure compliance. As our findings demonstrate, donors are concerned, at least in part, on how stable the environment is for their investment, which then leads to transitional justice accountability. However, if a postconflict state is fragmented or unstable, donors might view that state as high risk and avoid allocating aid for TJ purposes. 
${ }^{1}$ Andrew G. Reiter, 'Authoritarian Regime and Transition Type Dataset', Online, 2009, https://transitionaljusticedata.com/download. We refer to all recipient states included in our sample as post-authoritarian states. These states were taken using the standard of the Authoritarian Regime and Transition Type Dataset, which uses Polity to comprise a universe of states that have begun the transition from authoritarianism to democracy.

2 Jon Elster, Closing the Books: Transitional Justice in Historical Perspective (Cambridge University Press, 2004); Tricia D. Olsen, Leigh A. Payne, and Andrew G. Reiter, 'At What Cost? The Political Economy of Transitional Justice', Taiwan Journal of Democracy 6, no. 1 (2010): 165-84.

${ }^{3}$ Mark Osiel, Mass Atrocity, Collective Memory, and the Law (Brunswick, NJ: Transaction Publishers, 1999), 137-41; Leslie Vinjamuri and Jack Snyder, 'Law and Politics in Transitional Justice', Annual Review of Political Science 18 (2015): 303-27.

${ }^{4}$ Jon Elster, ed., Retribution and Reparation in the Transition to Democracy (Cambridge University Press, 2006).

${ }^{5}$ Olsen, Payne, and Reiter, 'At What Cost? The Political Economy of Transitional Justice'.

${ }^{6}$ Vinjamuri and Snyder, 'Law and Politics in Transitional Justice'.

7 Tricia D. Olsen, Leigh A. Payne, and Andrew G. Reiter, 'The Justice Balance: When Transitional Justice Improves Human Rights and Democracy', Human Rights Quarterly 32, no. 4 (2010): 980-1007.

${ }^{8}$ Annie R. Bird, U.S. Foreign Policy on Transitional Justice (Oxford and New York: Oxford University Press, 2015); Zachary D. Kaufman, United States Law and Policy on Transitional Justice: Principles, Politics, and Pragmatics (New York: Oxford University Press, 2016).

${ }^{9}$ William Muck and Eric Wiebelhaus-Brahm, 'External Transitional Justice Funding: Introducing a New Dataset', Journal of Peacebuilding and Development 11, no. 2 (2016): 66-71; Steven D. Roper and Lilian A. Barria, 'Gatekeeping versus Allocating in Foreign Assistance: Donor Motivations and Contributions to War Crimes Tribunals', Journal of Conflict Resolution 51, no. 2 (2007): 285-304.

${ }^{10}$ Alberto Alesina and David Dollar, 'Who Give Foreign Aid to Whom and Why?', Journal of Economic Growth 5, no. 1 (2000): 33-66.

${ }^{11}$ Stephen Knack, 'Does Foreign Aid Promote Democracy?', International Studies Quarterly 48, no. 1 (2004): 251-66; James M. Scott and Carrie A. Steele, 'Sponsoring Democracy: The United States and Democracy Aid to the Developing World, 1988-2001', International Studies Quarterly 55 (2011): 47-69.

${ }^{12}$ Muck and Wiebelhaus-Brahm, 'External Transitional Justice Funding: Introducing a New Dataset', 68.

${ }^{13}$ Roper and Barria, 'Gatekeeping versus Allocating in Foreign Assistance: Donor Motivations and Contributions to War Crimes Tribunals'.

${ }^{14}$ Ellen Lutz and Kathryn Sikkink, 'The Justice Cascade: The Evolution and Impact of Foreign Human Rights Trials in Latin America', Chicago Journal of International Law 2, no. 1 (2001): 1-34; Kathryn Sikkink, The Justice Cascade: How Human Rights Prosecutions Are Changing World Politics (NY: WW Norton and Company, Inc., 2011); Kathryn Sikkink, 'The Age of Accountability: The Global Rise of Individual Criminal Accountability', in Amnesty in the Age of Accountability: Comparative and International Perspectives (Cambridge University Press, 2012). 
15 Tricia D. Olsen, Leigh A. Payne, and Andrew G. Reiter, Transitional Justice in Balance: Comparing Processes, Weighing Efficacy (Washington, D.C.: United States Institute of Peace Press, 2010), 11.

${ }^{16}$ Olsen, Payne, and Reiter, Transitional Justice in Balance: Comparing Processes, Weighing Efficacy; Melissa Nobles, 'The Prosecution of Human Rights Violations', Annual Review of Political Science 13, no. 1 (2010): 165-82.

${ }^{17}$ Vinjamuri and Snyder, 'Law and Politics in Transitional Justice'.

${ }^{18}$ Martha Minow, Between Vengeance and Forgiveness: Facing History after Genocide and Mass Violence (Boston, MA: Beacon Press, 1998).

${ }^{19}$ Olsen, Payne, and Reiter, 'The Justice Balance: When Transitional Justice Improves Human Rights and Democracy'.

${ }^{20}$ Olsen, Payne, and Reiter, 'The Justice Balance: When Transitional Justice Improves Human Rights and Democracy'; Olsen, Payne, and Reiter, Transitional Justice in Balance: Comparing Processes, Weighing Efficacy.

${ }^{21}$ Jelena Subotić, 'The Transformation of International Transitional Justice Advocacy', International Journal of Transitional Justice 6, no. 1 (2012): 120.

22 Jon Elster, ed., Retribution and Reparation in the Transition to Democracy (Cambridge University Press, 2006).

${ }^{23}$ Bird, U.S. Foreign Policy on Transitional Justice; Kaufman, United States Law and Policy on Transitional Justice: Principles, Politics, and Pragmatics.

${ }^{24}$ Rajeev Bhargava, 'Restoring Decency to Barbaric Societies', in Truth v. Justice, ed. Robert Rotberg and Dennis Thompson (Princeton, NJ: Princeton University Press, 2000), 54.

${ }^{25}$ Idean Salehyan and Kristian Skrede Gleditsch, 'Refugees and the Spread of Civil War', International Organization 60, no. 2 (2006): 335-66.

${ }^{26}$ Osiel, Mass Atrocity, Collective Memory, and the Law, 137-41.

${ }^{27}$ Kaufman, United States Law and Policy on Transitional Justice: Principles, Politics, and Pragmatics, 44.

${ }^{28}$ Peter J. Boettke and Christopher J. Coyne, 'Political Economy of Forgiveness', Society 44, no. 2 (2007): 53-59.

${ }^{29}$ Vinjamuri and Snyder, 'Law and Politics in Transitional Justice', 307.

${ }^{30}$ Sikkink, 'The Age of Accountability: The Global Rise of Individual Criminal Accountability'.

${ }^{31}$ Hun Joon Kim, 'Structural Determinants of Human Rights Prosecution after Democratic Transition', Journal of Peace Research 49, no. 2 (2012): 305-20; Hunjoon Kim and Kathryn Sikkink, 'Explaining the Deterrence Effect of Human Rights Prosecutions for Transitional Countries', International Studies Quarterly 54, no. 4 (2010): 939-63.

${ }^{32}$ Elster, Closing the Books: Transitional Justice in Historical Perspective; Marek M. Kaminski, Monika Nalepa, and Barry O’Neill, 'Normative and Strategic Aspects of Transitional Justice', Journal of Conflict Resolution 50, no. 3 (2006): 295-302.

${ }^{33}$ We acknowledge that as TJ has grown more complex, and required more resources, that hybrid processes also exist.

${ }^{34}$ Samuel P. Huntington, The Third Wave: Democratization in the Late 20th Century (Norman, OK: University of Oklahoma Press, 1991); Nobles, 'The Prosecution of Human Rights

Violations'; Kim, 'Structural Determinants of Human Rights Prosecution after Democratic Transition'.

${ }^{35}$ Olsen, Payne, and Reiter, 'The Justice Balance: When Transitional Justice Improves Human Rights and Democracy', 13-14. 
${ }^{36}$ Lesli Vinjamuri and Jack Snyder, 'Advocacy and Scholarship in the Study of International War Crimes Tribunals and Transitional Justice', Annual Review of Political Science 7 (May 2004): $345-62$.

${ }^{37}$ Stephen Holmes, 'The End of Decommunization', East European Constitutional Review, 1994; Carlos S Nino, Radical Evil on Trial (New Haven, CT: Yale University Press, 1996).

${ }^{38}$ Hun Joon Kim, 'Expansion of Transitional Justice Measures: A Comparative Analysis of Its Causes' (PhD diss., University of Minnesota, 2008); Kim, 'Structural Determinants of Human Rights Prosecution after Democratic Transition'; Olsen, Payne, and Reiter, 'The Justice Balance: When Transitional Justice Improves Human Rights and Democracy'.

${ }^{39}$ Olsen, Payne, and Reiter, 'The Justice Balance: When Transitional Justice Improves Human Rights and Democracy'.

${ }^{40}$ Huntington, The Third Wave: Democratization in the Late 20th Century.

${ }^{41}$ Nobles, 'The Prosecution of Human Rights Violations'; Huntington, The Third Wave: Democratization in the Late 20th Century.

${ }^{42}$ Nobles, 'The Prosecution of Human Rights Violations', 168.

${ }^{43}$ Benjamin J. Appel and Cyanne E. Loyle, 'The Economic Benefits of Justice: Post-Conflict Justice and Foreign Direct Investment', Journal of Peace Research 49, no. 5 (2012): 685-99. ${ }^{44}$ Michael J. Hogan, The Marshall Plan: America, Britain and the Reconstruction of Western Europe, 1947-1952 (Cambridge, UK: Cambridge University Press, 1987).

${ }^{45}$ Michael J. Tierney et al., 'More Dollars than Sense: Refining Our Knowledge of Development Finance Using AidData', World Development 39, no. 11 (2011): 1891-1906.

${ }^{46}$ Ibid.

${ }^{47}$ Peter Boone, 'Politics and the Effectiveness of Aid', European Economic Review 40, no. 2 (1996): 289-329; Craig Burnside and David Dollar, 'Aid, Policies, and Growth', American Economic Review 90, no. 4 (2000): 847-68; Alesina and Dollar, 'Who Give Foreign Aid to Whom and Why?'; William Easterly, Ross Levine, and David Roodman, 'Aid, Policies, and Growth: Comment', American Economic Review 94, no. 3 (2004): 774-80.

${ }^{48}$ Robert D. McKinlay and Richard Little, 'A Foreign Policy Model of U.S. Bilateral Aid Allocation', World Politics 30, no. 1 (1977): 58-86; David A. Baldwin, Economic Statecraft (Princeton: Princeton University Press, 1985); Alesina and Dollar, 'Who Give Foreign Aid to Whom and Why?'

${ }^{49}$ Stephen Knack, 'Does Foreign Aid Promote Democracy?', International Studies Quarterly 48, no. 1 (2004): 251-66.

${ }^{50}$ Steven Finkel, Aníbal Pérez-Liñán, and Mitchell Seligson, 'The Effects of U.S. Foreign Assistance on Democracy Building, 1990-2003', World Politics 5, no. 3 (2007): 404-39; Scott and Steele, 'Sponsoring Democracy: The United States and Democracy Aid to the Developing World, 1988-2001'.

${ }^{51}$ Due to data limitations, we are unable to provide a targeted aid type equivalent to democracy aid/human rights aid/transitional justice aid for our analysis. We do provide several robustness checks, including using an imperfect measure of a human rights aid variable in Tables 3 and 4 of our online appendix.

${ }^{52}$ Burcu Savun and Daniel C. Tirone, 'Foreign Aid, Democratization, and Civil Conflict: How Does Democracy Aid Affect Civil Conflict?', American Journal of Political Science 55, no. 2 (2011): 233-46.

${ }^{53}$ Olsen, Payne, and Reiter, 'The Justice Balance: When Transitional Justice Improves Human Rights and Democracy'. 
${ }^{54}$ William H. Meyer, Human Rights and International Political Economy in Third World Nations (Westport: Praeger, 1998); M. Rodwan Abouharb and David L. Cingranelli, 'The Human Rights Effects of World Bank Structural Adjustment, 1981-2000'.

${ }^{55}$ David L. Cingranelli and Thomas E. Pasquarello, 'Human Rights Practices and the Distribution of U.S. Foreign Aid to Latin America', American Journal of Political Science, 1985. ${ }^{56}$ James M. McCormick and Neil Mitchell, 'Is US Aid Really Linked to Human Rights in Latin America?', American Journal of Political Science 32, no. 1 (1988): 231-39.

${ }^{57}$ Richard A. Nielsen, 'Rewarding Human Rights? Selective Aid Sanctions against Repressive States', International Studies Quarterly 57 (2013): 791-803.

${ }^{58}$ David L. Richards, Ronald D. Gelleny, and David H. Sacko, 'Money with a Mean Streak? Foreign Economic Penetration and Government Respect for Human Rights in Developing Countries', International Studies Quarterly 45, no. 2 (2001): 219-39.

${ }^{59}$ Paige Arthur, 'Why Do Donors Choose to Fund Transitional Justice?', in Transitional Justice, International Assistance, and Civil Society, ed. Paige Arthur and Christalla Yakinthou (Cambridge University Press, 2018).

${ }^{60}$ Ibid.

${ }^{61}$ Ibid.

${ }^{62}$ Roper and Barria, 'Gatekeeping versus Allocating in Foreign Assistance: Donor Motivations and Contributions to War Crimes Tribunals'; Olsen, Payne, and Reiter, 'At What Cost? The Political Economy of Transitional Justice'.

${ }^{63}$ Robert W. Rauchhaus, 'Principal-Agent Problems in Humanitarian Intervention: Moral Hazards, Adverse Selection, and the Commitment Dilemma', International Studies Quarterly 53, no. 4 (2009): 871-84.

${ }^{64}$ Timothy W. Crawford and Alan J. Kuperman, eds., Gambling on Humanitarian Intervention: Moral Hazard, Rebellion, and Civil War (Abingdon, UK: Routledge, 2006).

${ }^{65}$ Rauchhaus, 'Principal-Agent Problems in Humanitarian Intervention: Moral Hazards, Adverse Selection, and the Commitment Dilemma'.

${ }^{66}$ Arthur, 'Why Do Donors Choose to Fund Transitional Justice?'

${ }^{67}$ Ibid.

${ }^{68}$ Ibid., 227.

${ }^{69}$ Ibid., 222-23.

${ }^{70}$ Ibid., 222.

${ }^{71}$ Roper and Barria, 'Gatekeeping versus Allocating in Foreign Assistance: Donor Motivations and Contributions to War Crimes Tribunals'.

${ }^{72}$ Appel and Loyle, 'The Economic Benefits of Justice: Post-Conflict Justice and Foreign Direct Investment'.

${ }^{73}$ Elster, Closing the Books: Transitional Justice in Historical Perspective; Olsen, Payne, and Reiter, 'At What Cost? The Political Economy of Transitional Justice'.

${ }^{74}$ Lutz and Sikkink, 'The Justice Cascade: The Evolution and Impact of Foreign Human Rights Trials in Latin America'; Sikkink, The Justice Cascade: How Human Rights Prosecutions Are Changing World Politics; Sikkink, 'The Age of Accountability: The Global Rise of Individual Criminal Accountability'.

${ }^{75} \mathrm{We}$ created a reparative/restorative justice equivalent dependent variable made up of truth commissions, reparations, and amnesties. Results are reported in Table 7 in the online appendix. Aid has no significant effect on the implementation of reparative/restorative justice mechanisms in comparison to trials. 
${ }^{76}$ Reiter, 'Authoritarian Regime and Transition Type Dataset'. ARTT provides data on transitions from 1970 to 2004 and details on the length of the regime prior to democratization, the nature of this regime (such as one-party rule, military governance, or personalistic dictatorship), and the nature of transition (i.e., from civil war, negotiated settlement led by the government, or negotiated settlement led by the democratic opposition). Democratic transitions are determined from Polity IV coverage, with Reiter utilizing Polity IV's regime transition coding that includes cases of major democratic transition, minor democratic transition, as well as when a state moves from autocracy to partial or full democracy.

${ }^{77}$ Reiter, para. 1.

${ }^{78}$ Huntington, The Third Wave: Democratization in the Late 20th Century.

${ }^{79}$ Leigh Payne, Tricia D. Olsen, and Andrew G. Reiter, 'Transitional Justice Database Project', ([dataset]; accessed March 10, 2017), http://www.tjdproject.com/.

${ }^{80}$ Lessa and Payne, Amnesty in the Age of Human Rights Accountability: Comparative and International Perspectives; There are limitations with operationalizing trials as purely focused on individual criminal accountability and amnesties as purely focused on immunity. A growing body of qualitative research explores the limitations of this dichotomy. Lessa and Payne's edited volume, for example, convincingly argues that amnesties are not necessarily antithetical to the goals of the growing accountability norms. The Transitional Justice Database Project, which is utilized in this piece, does not identify the degree to which trials or amnesties are focused on the goals of individual criminal accountability in a systematic, quantitative manner.

${ }^{81}$ AidData 3.0, is the most recently available version of the dataset. AidData 3.0 only includes commitments of aid, however, leading us to use AidData 2.1 in this study instead.

${ }^{82}$ Tierney et al., 'More Dollars than Sense: Refining Our Knowledge of Development Finance Using AidData'. We exclude foreign aid from any non-state donors such as the UN for the purposes of this study.

${ }^{83} \mathrm{We}$ included disbursements of aid in initial analyses for robustness check purposes. The results are available in Tables 1 and 2 of the Online Appendix.

${ }^{84}$ Nonetheless, we provide results using human rights aid taken from AidData 2.1 Purpose Code 15160 in the Online Appendix.

${ }^{85}$ Guillermo O'Donnell, Philippe C. Schmitter, and Laurence Whitehead, eds., Transitions from Authoritarian Rule: Tentative Conclusions about Uncertain Democracies (Baltimore, MD: Johns Hopkins University Press, 1986).

${ }^{86}$ Huntington, The Third Wave: Democratization in the Late 20th Century, 215.

${ }^{87}$ Reiter, 'Authoritarian Regime and Transition Type Dataset', codebook: 7.

${ }^{88}$ Christian Davenport and David A. Armstrong II, 'Democracy and the Violation of Human

Rights: A Statistical Analysis from 1976-1996', American Journal of Political Science 48 (2004): 538-54; Christian Davenport, 'State Repression and Political Order', Annual Review of Political Science 10 (2007): 1-23.

${ }^{89}$ Peter J. Schraeder, Steven W. Hook, and Bruce Taylor, 'Clarifying the Foreign Aid Puzzle: A Comparison of American, Japanese, French, and Swedish Aid Flows', World Politics 50, no. 2 (1998): 294-323; Alesina and Dollar, 'Who Give Foreign Aid to Whom and Why?'

${ }^{90}$ Victor Asal, Udi Sommer, and Paul G. Harwood, 'Original Sin: A Cross-National Study of the Legality of Homosexual Acts', Comparative Political Studies 46, no. 3 (2012): 320-51.

${ }^{91}$ Maureen Wilson, 'Post-Conflict Justice and Legal Traditions: A New Conceptual Framework' (PhD diss., Kennesaw State University, 2019).

${ }^{92}$ Alesina and Dollar, 'Who Give Foreign Aid to Whom and Why?' 
${ }^{93}$ Steven C. Poe and C. Neal Tate, 'Repression of Human Rights to Personal Integrity in the 1980s: A Global Analysis', American Political Science Review 88 (1994): 853-72; Steven C.

Poe, C. Neal Tate, and Linda Camp Keith, 'Repression of the Human Right to Personal Integrity Revisited: A Global Cross-National Study Covering the Years 1976-1993', International Studies Quarterly 43, no. 2 (1999): 291-313.

${ }^{94}$ Appel and Loyle, 'The Economic Benefits of Justice: Post-Conflict Justice and Foreign Direct Investment'. As highlighted by Appel and Loyle, there may be an issue with selection effects and endogeneity in our sample. Given this, we provide endogeneity tests in Table 5 of the online appendix.

${ }^{95}$ Huntington, The Third Wave: Democratization in the Late 20th Century; Vinjamuri and Snyder, 'Advocacy and Scholarship in the Study of International War Crimes Tribunals and Transitional Justice'.

${ }^{96} \mathrm{Kim}$, 'Expansion of Transitional Justice Measures: A Comparative Analysis of Its Causes'; Kim, 'Structural Determinants of Human Rights Prosecution after Democratic Transition'.

${ }^{97}$ Bird, U.S. Foreign Policy on Transitional Justice.

${ }^{98}$ Olsen, Payne, and Reiter, Transitional Justice in Balance: Comparing Processes, Weighing Efficacy.

${ }^{99}$ Appel and Loyle, 'The Economic Benefits of Justice: Post-Conflict Justice and Foreign Direct Investment'.

${ }^{100}$ Initial tests found in the Appendix suggest that amnesties might be a particularly powerful signal from potential recipient states to donors regarding state stability.

${ }^{101}$ Laia Balcells and Stathis N. Kalyvas, 'Does Warfare Matter? Severity, Duration, and Outcomes of Civil Wars', Journal of Conflict Resolution 58, no. 8 (2014): 1390-1418. 


\section{For Reviewer and Online Appendix Use Only}

Aid for Justice? Analyzing the Impact of Foreign Aid on Recipient Transitional Justice Implementation

\section{Appendix:}

Table 1: Negative Binomial Regression, The Effect of Total Aid Disbursements on Transitional

Justice Implementation in Post-Authoritarian States

\begin{tabular}{|c|c|}
\hline VARIABLES & $\begin{array}{c}(1) \\
\mathrm{TJ}_{t+1} \\
\end{array}$ \\
\hline Disbursements (ln) & $\begin{array}{c}-0.00979 \\
(0.036)\end{array}$ \\
\hline Fariss Human Rights & $\begin{array}{c}-0.40711^{* * *} \\
(0.139)\end{array}$ \\
\hline Polity 2 & $\begin{array}{c}-0.02318 \\
(0.016)\end{array}$ \\
\hline Population (ln) & $\begin{array}{c}-0.05249 \\
(0.089)\end{array}$ \\
\hline GDP per capita $(\ln )$ & $\begin{array}{c}-0.13222 \\
(0.096)\end{array}$ \\
\hline International Conflict & $\begin{array}{c}0.13743 \\
(0.314)\end{array}$ \\
\hline Civil Conflict & $\begin{array}{c}0.08581 \\
(0.291)\end{array}$ \\
\hline HRO Count & $\begin{array}{c}0.05547 \\
(0.166)\end{array}$ \\
\hline English Origin & $\begin{array}{c}1.40151 * * \\
(0.570)\end{array}$ \\
\hline French Origin & $\begin{array}{c}0.88023 \\
(0.547)\end{array}$ \\
\hline SocComm Legal Origin & $\begin{array}{c}1.28037 * * * \\
(0.492)\end{array}$ \\
\hline Age of Democracy & $\begin{array}{c}-0.00790 * * * \\
(0.003)\end{array}$ \\
\hline Civil War Transition & $\begin{array}{c}-0.22700 \\
(0.677)\end{array}$ \\
\hline Collapse & $\begin{array}{c}18.38218 * * * \\
(1.665)\end{array}$ \\
\hline Overthrow & $\begin{array}{c}18.99938 * * * \\
(1.415)\end{array}$ \\
\hline Sudden Transition & $-17.58527 * * *$ \\
\hline
\end{tabular}




\begin{tabular}{lc} 
& $(0.257)$ \\
Constant & -1.57030 \\
& $(1.343)$ \\
Observations & 1,380 \\
\hline
\end{tabular}

Robust standard errors in parentheses $* * * \mathrm{p}<0.01, * * \mathrm{p}<0.05, * \mathrm{p}<0.1$

Table 2: Logistic Regression, The Effect of Total Aid Disbursements and Political Risk on Transitional Justice Implementation in Post-Authoritarian States

\begin{tabular}{|c|c|}
\hline VARIABLES & $\begin{array}{c}(1) \\
\text { Binary } \mathrm{TJ}_{t+1}\end{array}$ \\
\hline Disbursements (ln) & $\begin{array}{c}0.09051 \\
(0.255)\end{array}$ \\
\hline Political Risk & $\begin{array}{c}0.02704 \\
(0.077)\end{array}$ \\
\hline Disbursements*Risk & $\begin{array}{c}-0.00242 \\
(0.004)\end{array}$ \\
\hline Fariss Human Rights & $\begin{array}{c}-0.34499 \\
(0.272)\end{array}$ \\
\hline Polity 2 & $\begin{array}{c}-0.00111 \\
(0.031)\end{array}$ \\
\hline Population (ln) & $\begin{array}{c}-0.01560 \\
(0.160)\end{array}$ \\
\hline GDP per capita (ln) & $\begin{array}{c}-0.19638 \\
(0.148)\end{array}$ \\
\hline Interstate Conflict & $\begin{array}{c}1.05788 \\
(0.659)\end{array}$ \\
\hline Civil Conflict & $\begin{array}{c}-1.01400 \\
(0.666)\end{array}$ \\
\hline HRO Count (ln) & $\begin{array}{c}0.44286 \\
(0.418)\end{array}$ \\
\hline English Origin & $\begin{array}{c}0.71257 \\
(1.008)\end{array}$ \\
\hline French Origin & $\begin{array}{c}0.31537 \\
(1.074)\end{array}$ \\
\hline SocComm Origin & $\begin{array}{c}1.23841 \\
(1.218)\end{array}$ \\
\hline Age of Democracy & $\begin{array}{c}-0.00655 \\
(0.006)\end{array}$ \\
\hline Collapse & $\begin{array}{c}0.82066 \\
(1.597)\end{array}$ \\
\hline
\end{tabular}




\begin{tabular}{lc} 
Overthrow & 1.49939 \\
& $(1.381)$ \\
Constant & -2.99257 \\
& $(4.854)$ \\
Observations & 748 \\
\hline
\end{tabular}

Robust standard errors in parentheses $* * * \mathrm{p}<0.01, * * \mathrm{p}<0.05, * \mathrm{p}<0.1$

Table 3: Negative Binomial Regression, The Effect of Human Rights Aid Commitments on Transitional Justice Implementation in Post-Authoritarian States

\begin{tabular}{|c|c|c|}
\hline VARIABLES & $\begin{array}{c}(1) \\
\mathrm{TJ}_{t+1}\end{array}$ & $\begin{array}{c}(2) \\
\text { Trial }_{t+1}\end{array}$ \\
\hline HR Commitments (ln) & $\begin{array}{c}0.06954 \\
(0.059)\end{array}$ & $\begin{array}{c}0.41654 * * * \\
\quad(0.143)\end{array}$ \\
\hline Fariss Human Rights & $\begin{array}{c}-0.42508 * * \\
(0.211)\end{array}$ & $\begin{array}{c}-1.17092 * * \\
(0.562)\end{array}$ \\
\hline Polity 2 & $\begin{array}{c}-0.02609 \\
(0.025)\end{array}$ & $\begin{array}{c}0.08906 \\
(0.057)\end{array}$ \\
\hline Population (ln) & $\begin{array}{c}-0.16436 \\
(0.169)\end{array}$ & $\begin{array}{c}-0.87566^{*} \\
(0.519)\end{array}$ \\
\hline GDP per capita (ln) & $\begin{array}{c}0.11366 \\
(0.200)\end{array}$ & $\begin{array}{c}0.58386 \\
(0.411)\end{array}$ \\
\hline International Conflict & $\begin{array}{c}0.31807 \\
(0.551)\end{array}$ & $\begin{array}{c}-17.30755^{* * * *} \\
(1.226)\end{array}$ \\
\hline Civil Conflict & $\begin{array}{c}-0.27201 \\
(0.457)\end{array}$ & $\begin{array}{c}15.58987 * * * \\
(0.950)\end{array}$ \\
\hline HRO Count & $\begin{array}{c}0.33951 \\
(0.421)\end{array}$ & $\begin{array}{c}-1.38156 \\
(1.382)\end{array}$ \\
\hline English Origin & $\begin{array}{c}14.28514 * * * \\
(0.739)\end{array}$ & $\begin{array}{c}18.21722 * * * \\
(4.615)\end{array}$ \\
\hline French Origin & $\begin{array}{c}14.80159 * * * \\
(0.831)\end{array}$ & $\begin{array}{l}1.65994 \\
(4.212)\end{array}$ \\
\hline SocComm Origin & $\begin{array}{c}15.17623^{* * *} \\
(1.067)\end{array}$ & $\begin{array}{c}-11.60208 \\
\text { (.) }\end{array}$ \\
\hline Age of Democracy & $\begin{array}{c}-0.00202 \\
(0.004)\end{array}$ & $\begin{array}{c}0.01890 \\
(0.012)\end{array}$ \\
\hline Civil War Transition & $\begin{array}{c}-14.33807 * * * \\
(1.067)\end{array}$ & $\begin{array}{c}-21.78038 * * * \\
(1.334)\end{array}$ \\
\hline Collapse & $\begin{array}{c}0.38692 \\
(0.668)\end{array}$ & $\begin{array}{l}1.11287 \\
(0.874)\end{array}$ \\
\hline Overthrow & $-13.79220 * * *$ & $-2.59970 *$ \\
\hline
\end{tabular}




\begin{tabular}{lcc} 
& $(1.115)$ & $(1.427)$ \\
Constant & $-31.33250^{* * * *}$ & $-40.19481^{* * * *}$ \\
& $(2.422)$ & $(3.394)$ \\
Observations & 450 & 450 \\
\hline
\end{tabular}

Robust standard errors in parentheses

$* * * \mathrm{p}<0.01, * * \mathrm{p}<0.05, * \mathrm{p}<0.1$

Table 4: The Effect of Total Aid Commitments and Political Risk on Transitional Justice Implementation in Post-Authoritarian States

\begin{tabular}{|c|c|c|}
\hline VARIABLES & $\begin{array}{c}(1) \\
\text { Binary } \mathrm{TJ}_{t+1}\end{array}$ & $\begin{array}{c}(2) \\
\text { Count of } \mathrm{TJ}_{t+1}\end{array}$ \\
\hline HR Commitments (ln) & $\begin{array}{c}-0.16672 \\
(0.371)\end{array}$ & $\begin{array}{c}-0.21470 \\
(0.259)\end{array}$ \\
\hline Political Risk & $\begin{array}{c}-0.08618 \\
(0.090)\end{array}$ & $\begin{array}{c}-0.08843 \\
(0.066)\end{array}$ \\
\hline Commitments*Risk & $\begin{array}{c}0.00365 \\
(0.006)\end{array}$ & $\begin{array}{c}0.00434 \\
(0.005)\end{array}$ \\
\hline Fariss Human Rights & $\begin{array}{c}-0.28415 \\
(0.388)\end{array}$ & $\begin{array}{c}-0.32731 \\
(0.326)\end{array}$ \\
\hline Polity 2 & $\begin{array}{c}0.03186 \\
(0.044)\end{array}$ & $\begin{array}{c}0.03214 \\
(0.039)\end{array}$ \\
\hline Population (ln) & $\begin{array}{c}-0.17825 \\
(0.235)\end{array}$ & $\begin{array}{c}-0.26605 \\
(0.219)\end{array}$ \\
\hline GDP per capita (ln) & $\begin{array}{c}0.20303 \\
(0.209)\end{array}$ & $\begin{array}{c}0.01400 \\
(0.189)\end{array}$ \\
\hline Interstate Conflict & $\begin{array}{l}1.58839 \\
(1.396)\end{array}$ & $\begin{array}{c}0.45505 \\
(0.660)\end{array}$ \\
\hline Civil Conflict & $\begin{array}{c}-1.69649 \\
(1.352)\end{array}$ & $\begin{array}{c}-0.76862 \\
(0.611)\end{array}$ \\
\hline HRO Count (ln) & $\begin{array}{c}0.49690 \\
(0.666)\end{array}$ & $\begin{array}{c}0.95287 \\
(0.581)\end{array}$ \\
\hline English Origin & $\begin{array}{c}14.90020 * * * \\
(0.518)\end{array}$ & $\begin{array}{c}14.07173 * * * \\
(0.954)\end{array}$ \\
\hline French Origin & $\begin{array}{c}15.27010 * * * \\
(1.058)\end{array}$ & $\begin{array}{c}14.81416 * * * \\
(1.180)\end{array}$ \\
\hline SocComm Origin & $\begin{array}{c}16.30758 * * * \\
(1.357)\end{array}$ & $\begin{array}{c}15.87758 * * * \\
(1.421)\end{array}$ \\
\hline Age of Democracy & $\begin{array}{c}-0.00352 \\
(0.007)\end{array}$ & $\begin{array}{c}0.00076 \\
(0.006)\end{array}$ \\
\hline Collapse & $\begin{array}{c}0.65282 \\
(1.324)\end{array}$ & $\begin{array}{c}0.17700 \\
(0.796)\end{array}$ \\
\hline
\end{tabular}




\begin{tabular}{lcc} 
Civil War Transition & $-15.01421 * * *$ \\
& & $(1.092)$ \\
Overthrow & $-14.21415^{* * *}$ \\
& & $(1.148)$ \\
Constant & $-14.36216^{* * *}$ & $-27.23598^{* * *}$ \\
& $(5.376)$ & $(4.276)$ \\
Observations & 373 & 382 \\
\hline
\end{tabular}

Robust standard errors in parentheses $* * * \mathrm{p}<0.01, * * \mathrm{p}<0.05, * \mathrm{p}<0.1$

Testing for Endogeneity:

Table 5: The Effect of Counts of Transitional Justice Mechanisms on Foreign Aid Commitment Totals in Post-Authoritarian States

(1) (2)

\begin{tabular}{lll} 
VARIABLES & Commitments $(\ln )_{t+1} \quad$ Commitments $(\ln )_{t+1}$ \\
\hline
\end{tabular}

Transitional Justice (count) $\quad 0.04256$

Amnesty

(0.036)

Trials

$-0.03999$

(0.087)

Fariss Human Rights

0.02319

0.01506

Polity 2

(0.104)

$(0.105)$

0.00993

0.01030

(0.012)

(0.012)

Population (ln)

$0.69175 * * *$

(0.139)

$0.69044 * * *$

GDP per capita (ln)

$-0.36555^{*}$

(0.139)

(0.219)

$-0.37271 *$

International Conflict

$-0.18335$

(0.219)

$-0.19673$

(0.252)

(0.253)

Civil Conflict

0.15299

0.16570

(0.249)

(0.250)

HRO Count (ln)

$0.38622 *$

(0.213)

English Origin

$-0.20294$

(0.797)

$0.38477 *$

(0.213)

$-0.17816$

French Origin

0.10750

(0.803)

(0.932)

SocComm Origin

$-0.37054$

0.12834

(0.937)

(0.698)

$-0.35171$

Age of Democracy

0.00105

(0.700)

(0.003)

0.00100

Civil War Transition

0.20163

(0.003)

0.21162

(0.207)

(0.220) 


\begin{tabular}{lcc} 
Collapse & -1.36319 & -1.35751 \\
& $(1.282)$ & $(1.291)$ \\
Overthrow & $-1.60719^{*}$ & -1.56160 \\
& $(0.967)$ & $(0.966)$ \\
Sudden Transition & $1.57209^{*}$ & $1.58844^{*}$ \\
& $(0.910)$ & $(0.907)$ \\
Constant & $12.83205^{* * *}$ & $12.91162^{* * *}$ \\
& $(3.179)$ & $(3.179)$ \\
Observations & 1,606 & 1,606 \\
\hline
\end{tabular}

Robust standard errors in parentheses $* * * \mathrm{p}<0.01, * * \mathrm{p}<0.05, * \mathrm{p}<0.1$

Table 6: The Effect of Counts of Transitional Justice Mechanisms on Foreign Aid Disbursement Totals in Post-Authoritarian States

(1) (2)

\begin{tabular}{|c|c|c|}
\hline VARIABLES & Disbursements $(\ln )_{t+1}$ & Disbursements (11 \\
\hline Transitional Justice (count) & $\begin{array}{c}0.15707 * * \\
(0.063)\end{array}$ & \\
\hline Amnesty & & \\
\hline Trials & & $\begin{array}{c}0.09667 \\
(0.080)\end{array}$ \\
\hline Fariss Human Rights & $\begin{array}{c}0.57530 * * * \\
(0.123)\end{array}$ & $\begin{array}{c}0.55557 * * * \\
(0.122)\end{array}$ \\
\hline Polity 2 & $\begin{array}{c}-0.00525 \\
(0.016)\end{array}$ & $\begin{array}{c}-0.00493 \\
(0.016)\end{array}$ \\
\hline Population (ln) & $\begin{array}{c}0.76583 * * * \\
(0.109)\end{array}$ & $\begin{array}{c}0.76401 * * * \\
(0.110)\end{array}$ \\
\hline GDP per capita (ln) & $\begin{array}{c}-0.36719 * * \\
(0.150)\end{array}$ & $\begin{array}{c}-0.37174 * * \\
(0.151)\end{array}$ \\
\hline International Conflict & $\begin{array}{c}-0.04259 \\
(0.346)\end{array}$ & $\begin{array}{c}-0.06467 \\
(0.348)\end{array}$ \\
\hline Civil Conflict & $\begin{array}{c}-0.01935 \\
(0.367)\end{array}$ & $\begin{array}{c}-0.00301 \\
(0.370)\end{array}$ \\
\hline HRO Count & $\begin{array}{c}1.17578 * * * \\
(0.197)\end{array}$ & $\begin{array}{c}1.16747 * * * \\
(0.196)\end{array}$ \\
\hline English Origin & $\begin{array}{c}-0.47105 \\
(0.454)\end{array}$ & $\begin{array}{c}-0.42760 \\
(0.459)\end{array}$ \\
\hline French Origin & $\begin{array}{c}-0.18367 \\
(0.599)\end{array}$ & $\begin{array}{c}-0.15285 \\
(0.607)\end{array}$ \\
\hline SocComm Origin & $\begin{array}{c}-0.00570 \\
(0.437)\end{array}$ & $\begin{array}{c}0.04559 \\
(0.443)\end{array}$ \\
\hline Age of Democracy & $\begin{array}{c}0.00079 \\
(0.003)\end{array}$ & $\begin{array}{c}0.00060 \\
(0.003)\end{array}$ \\
\hline Civil War Transition & $0.47855 * *$ & $0.48039 * *$ \\
\hline
\end{tabular}




$\begin{array}{lcc} & (0.230) & (0.220) \\ \text { Collapse } & -1.73225^{* * *} & -1.65323 * * * \\ & (0.245) & (0.194) \\ \text { Overthrow } & -0.89526^{*} & -0.87321 * \\ & (0.534) & (0.519) \\ \text { Sudden Transition } & 1.14731^{* * *} & 1.26845^{* * *} \\ & (0.114) & (0.113) \\ \text { Constant } & 9.69369 * * * & 9.69693 * * * \\ & (2.315) & (2.326)\end{array}$

Observations

1,409

1,409

$$
\begin{gathered}
\text { Robust standard errors in parentheses } \\
* * * \mathrm{p}<0.01, * * \mathrm{p}<0.05, * \mathrm{p}<0.1
\end{gathered}
$$

\section{Testing Aggregate Measures of Reparative/Restorative Justice}

Table 7: The effects of foreign aid on aggregate measures of reparative/restorative justice

(1)

Aggregate

Reparative/Restorative Reparative/Restorative

(2)

Binary
Foreign Aid (ln)

Fariss Human Rights

Polity 2

Population (ln)

GDP per capita (ln)

International Conflict

Civil Conflict

HRO Count

English Origin

French Origin

SocComm Origin

German Origin

Scand Origin
0.09309

(0.067)

$-0.39297 * * *$

(0.143)

$-0.03072 *$

(0.018)

$-0.02148$

(0.104)

$-0.16028$

(0.098)

0.45639

(0.341)

$-0.10593$

(0.311)

0.00025

(0.182)

0.45727

(0.564)

0.06457

(0.554)

0.55446

(0.509)

1.05534

(0.708)

1.63293
0.08736

(0.068)

$-0.45337 * * *$

(0.154)

$-0.02755$

(0.020)

$-0.01324$

(0.108)

$-0.19741 *$

(0.111)

$0.94271 * *$

(0.469)

$-0.57434$

(0.467)

0.11769

(0.199)

0.22879

(0.605)

$-0.28210$

(0.610)

0.26195

(0.573) 


\begin{tabular}{lcc} 
& $(1.201)$ & \\
Age of Democracy & $-0.00784^{* *}$ & $-0.00859^{* *}$ \\
Civil War & $(0.003)$ & $(0.004)$ \\
& -0.06125 & 0.35463 \\
Collapse & $(0.567)$ & $(0.928)$ \\
& -1.24607 & - \\
Overthrow & $(0.995)$ & $13.43376^{* * * *}$ \\
Sudden & $15.43038^{* * *}$ & $(1.358)$ \\
& $(1.202)$ & $-13.32516^{* * *}$ \\
lnalpha & $-15.42057^{* * *}$ & $(0.773)$ \\
& $(0.754)$ & $-14.02298^{* * *}$ \\
Constant & & $(1.931)$ \\
& $-16.62446 * *$ & 1,528 \\
Observations & $(8.083)$ & \\
\hline
\end{tabular}

Robust standard errors in parentheses $* * * \mathrm{p}<0.01, * * \mathrm{p}<0.05, * \mathrm{p}<0.1$ 